\title{
Marketing Analysis Of Beef Cattle In Landono And Mowila Subdistricts Of South Konawe Regency
}

\author{
La Ode Arsad Sani ${ }^{1}$, Rahim Aka ${ }^{1}$, La Ode Muh Munadi*1, ${ }^{*}$ azak Ali ${ }^{1}$ \\ Muhammad Amrullah Pagala ${ }^{1}$, Syamsuddin ${ }^{1}$ \\ ${ }^{1}$ Faculty of Animal Husbandry, Halu Oleo University, Kampus Hijau Bumi \\ Tridharma, Anduonohu, Kendari, Southeast Sulawesi. \\ * Corresponding Author: \\ Email:1mmunadi@gmail.com
}

\begin{abstract}
.
Research has been conducted in Landono and Mowila Subdistricts of South Konawe Regency in October-December 2020. The subjects of the study were ranchers and beef cattle traders. Location determination is done intentionally (purposive sampling) while farmers who become respondents are taken as many as 60 people, consisting of 30 respondents each sub-district, which is determined randomly simple (simple random sampling). Research variables are characteristics of respondents including age, education, business experience, number of family members, channels and marketing institutions, margins, costs and profits between marketing agencies. The results showed marketing channels, namely, Farmers $\rightarrow$ The Final Consumer (Channel I), Farmers $\rightarrow$ End Consumer $\rightarrow$ Collectors (Channel II), Farmers $\rightarrow$ Large Traders $\rightarrow$ End Consumers (Channel III), Farmers $\rightarrow$ Collector Traders $\rightarrow$ Large Traders $\rightarrow$ The Final Consumer (Channel IV). Marketing margin on channel III (Rp 1,088,571/tail) and channel IV (Rp 1,088,571/tail), lowest on channel II (Rp 765,556/tail). The institutions that get the highest profit are large traders (Rp 998,571/tail), the lowest collector traders (Rp 575,556/tail).
\end{abstract}

Keywords: Marketing Channels, Beef Cattle, South Konawe.

\section{INTRODUCTION}

The role of the agricultural sector in sustainable development can be seen from the contribution of the agricultural sector to the national economy. The agricultural sector consists of subsectors of food crops, holticulture, forestry, plantations and farms, among the four subsectors that have an important role, the food sector has an important role in the provision of foodstuffs for the community in supporting the sustainability of life. Pagan plants consist of two large groups of rice and crops, crops are also directed in food security and poverty alleviation $[1,2,3,4]$.

The construction of farms is directed at increasing the production and income of farmers [5]. But it expanded to include integrated agribusiness development [6]. Farmers as the subject of development are pushed towards understanding the farm to be a source of income [3, 4]. Beef cattle farming is a business of high economic value. Thus, allowing farmers to earn enough income and one of the determining factors in the development of farms is an efficient marketing system [5, 6]. Beef cattle is a type 
of cattle that has considerable potential to be developed, and maintained with the main purpose as a meat producer, so it is often referred to as broilers [7, 8, 9].

Beef cattle that are kept in Southeast Sulawesi, especially in South Konawe Regency, are Bali cows. The population of beef cattle in 2019 amounted to 299,240 head spread throughout the district/city. The district with the largest beef cattle population is Muna Regency which is 66,777 heads (22\%), South Konawe Regency 62,616 heads (21\%), Bombana Regency 54,029 heads (18\%), Konawe Regency 43,285 heads $(14 \%)$, and 57,032 heads (19\%) spread across 13 other districts/cities. This shows that for cattle breeds located in some districts have a good opportunity or prospect in terms of managing livestock resources because it is supported by a large population [10,11]. Beef cattle have opportunities in terms of livestock development prospects in order to lead to national meat self-sufficiency $[12,13,14]$.

Landono and Mowila subdistricts are beef cattle development areas that have a large population in South Konawe. The population of beef cattle in Landono subdistrict in 2020 as much as 2,716 heads, or $6.74 \%$ and Mowila subdistrict as many as 3,311 heads, or $5.32 \%$, while the rest about $87.94 \%$ spread in 23 other subdistricts in the south Konawe district. The purpose of the research was to identify the pattern of beef cattle marketing channels on the farms of the people of Landono and Mowila subdistricts, analyze marketing margins at each marketing institution while analyzing marketing efficiency So that, the benefits of research can provide data and information on the marketing of beef cattle in the research area, in general South Konawe Regency.

\section{METHODS}

The research was conducted in October-December 2020 in Landono and Mowila Subdistricts, South Konawe Regency. The location of the study was determined by purposive sampling with the consideration that Landono and Mowila subdistricts have a beef cattle population of about $12.06 \%$ of the total beef cattle population in South Konawe Regency by 2020.

The research population of all peterrnak and beef cattle traders in Landono subdistrict consists of 21 villages and Mowila subdistrict consists of 20 villages. Furthermore, the selection of villages in each sub-district, selected by purposive sampling by selecting each of the three villages that have the most cow population. Research samples in each village are farmers and traders (intermediaries and collectors) who have bought and sold cattle. Traders were taken on a census basis and each sub-district was taken by 30 respondents each, bringing the total number of respondents to 60 .

The type of research data is the primary data of interview results with the help of quisioner and secondary data sourced from supporting literature in the form of books, journals, and related agencies. Research data collection techniques are conducted by observation, namely collecting data through observation and direct tracing on cattle breeder respondents. With variables observed are characteristics of respondents, 
marketing channels, marketing agencies, marketing margins, costs and profits. Furthermore, the data obtained is analyzed using the formula:

Marketing Margin:

Formula: $\mathbf{M}=\mathbf{H p}-\mathbf{H b}$

\section{Description:}

$\begin{array}{ll}\mathbf{M} & =\text { Marketing margin }(\mathrm{Rp} / \text { tail }) \\ \mathbf{H p} & =\text { Sales price }(\mathrm{Rp} / \text { tail }) \\ \mathbf{H b} & =\text { Purchase price }(\mathrm{Rp} / \text { tail })\end{array}$

\section{Fees and Benefits:}

Formula: $\pi=\mathrm{ML}-\mathrm{TC}$

\section{Description:}

$\Pi=\quad=$ Marketing agency profit $(\mathrm{Rp} /$ tail $)$

$\mathrm{ML} \quad=$ Margin of marketing institutions ( $\mathrm{Rp} /$ tail)

TC $=$ Total cost incurred by each marketing agency (Rp/tail)

\section{RESULT AND DISCUSSION}

\section{Beef Cattle Marketing Channel}

Beef cattle marketing channel is a channel of distribution of cattle from farmers with or without involving marketing agencies until it reaches the end consumer. Based on the results of observations and direct searches, it is known that the marketing of beef cattle in Mowila and Landono subdistricts there are several marketing channels involving several marketing agencies, namely farmers, gatherers, and large traders. More details of these marketing channels can be presented in Fig 1.

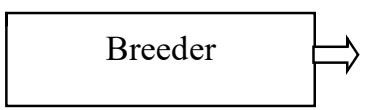

1.

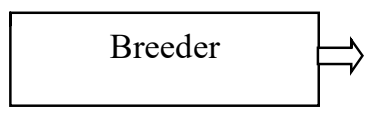

2.

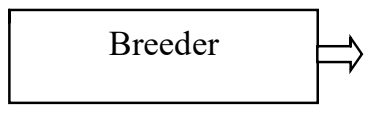

3.

\section{End Consumer}

End Consumer

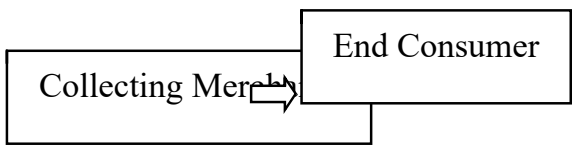


4.

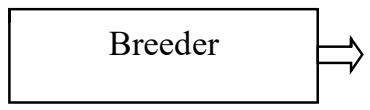

$$
\text { Collecting Merchants }
$$

Great Traders

Fig 1. Channel marketing of beef cattle at research sites.

\section{Marketing Channels I}

Marketing channel I is a direct marketing channel to consumers without going through intermediary traders that is from farmers directly to the end consumer. Direct marketing is marketing that is done to the end consumer without going through intermediary traders [19].

\section{Marketing Channels II}

Marketing channel II as in Fig. 2, involves 1 intermediary trader, namely the collecting trader. Farmers market cattle through collecting traders, then collectors market them to the end consumer.

\section{Marketing Channels III}

Marketing channel III, namely farmers sell their livestock through intermediary traders, namely large traders. Furthermore the big traders sell it to the end consumer. Consumers who buy cattle are residents around the research site and rph parties. Indirect marketing channels are marketing channels that go through marketing agencies such as collectors, modern markets, traditional markets and retailers [20].

\section{Marketing Channels IV}

Cattle marketing channel in South Konawe Regency on marketing channel IV through two marketing agencies to get to the end consumer, namely collectors and large traders. In this channel, the collecting trader comes directly to the location of the farm, so that all costs that will be incurred are borne by the trader.

\section{Marketing Margins}

The marketing margin of beef cattle is the difference in the price of cattle received by farmers and the price of cattle issued by the end consumer. The average price and marketing margin of beef cattle in South Konawe Regency is explained in Table 1.

Table 1. Average Price and Marketing Margin of Beef Cattle in Landono and Mowila Subdistricts of South Konawe Regency.

\begin{tabular}{|c|c|c|c|c|}
\hline Channels & Status & $\begin{array}{l}\text { Buy Price } \\
\text { (Rp/ Tail) }\end{array}$ & $\begin{array}{l}\text { Sale Price } \\
\text { (Rp/Tail) }\end{array}$ & Margin \\
\hline \multirow[b]{2}{*}{ I } & Breeder & & 6.040 .000 & - \\
\hline & End Consumer & 6.040 .000 & - & - \\
\hline Total & & & & - \\
\hline II & $\begin{array}{l}\text { Breeder } \\
\text { Collecting Merchants }\end{array}$ & $\begin{array}{c}- \\
6.040 .000\end{array}$ & $\begin{array}{l}6.040 .000 \\
6.805 .556\end{array}$ & $\begin{array}{c}- \\
765.556\end{array}$ \\
\hline
\end{tabular}


International Journal Of Science, Technology \& Management

\begin{tabular}{clccc} 
& End Consumer & 6.805 .556 & - & - \\
\hline Total & & & & $\mathbf{7 6 5 . 5 5 6}$ \\
\hline \multirow{3}{*}{ III } & Breeder & - & 6.040 .000 & - \\
& Great Traders & 6.040 .000 & 7.128 .571 & 1.088 .571 \\
& End Consumer & 7.128 .571 & - & - \\
\hline Total & & & & $\mathbf{1 . 0 8 8 . 5 7 1}$ \\
\hline \multirow{3}{*}{ IV } & Breeder & - & 6.040 .000 & - \\
& Collecting Merchants & 6.040 .000 & 6.805 .556 & 765.5561 \\
& Great Traders & 6.805 .556 & 7.128 .571 & 323.016 \\
& End Consumer & 7.128 .571 & - & - \\
\hline Total & & & & $\mathbf{1 . 0 8 8 . 5 7 1}$ \\
\hline
\end{tabular}

Marketing of beef cattle in South Konawe Regency through two ways, namely direct and indirect marketing. Direct marketing of cows is marketing by farmers directly to consumers, without going through intermediaries. This causes no difference in price or margin from farmers and consumers, such marketing occurs on marketing channels I. In marketing channels II and III only involve 1 intermediary trader with a margin of $\mathrm{Rp} \mathrm{765.556/tail} \mathrm{and} \mathrm{Rp}$ 1.088.571/tail, Respectively, while marketing channel IV involves 2 intermediary traders, namely collectors and large traders with

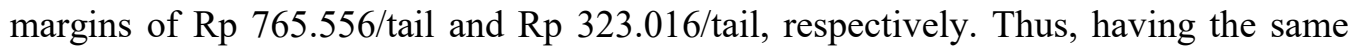
number of margins as marketing channels III, it is due to the similarity of the selling price of cattle at the level of farmers and traders with a margin of Rp 1.088.571 / head. The amount of marketing margin will be different on each marketing channel because each marketing agency has a different selling price $[21,5]$.

\section{Costs and Benefits}

The cost of marketing beef cattle is a cost incurred during the marketing process, ranging from cattle out of the hands of producers until accepted by consumers. The marketing costs are borne by the marketing agencies involved in the form of transportation, labor, and information costs.

Profit is the difference in the price paid by consumers with the price received by the manufacturer after deducting the marketing costs. Which states that profit is the price paid to the first seller and the price paid by the last buyer (margin) after deducting the marketing costs. The average cost and marketing benefits of beef cattle in South Konawe Regency are explained in Table 2.

Table 2. Cost and Profit of Beef Cattle Marketing in Landono and Mowila Subdistricts of South Konawe Regency.

\begin{tabular}{clccc}
\hline Channels & Marketing Institute & Margin & Costs & Benefits \\
\hline \multirow{2}{*}{ I } & Breeder & - & - & - \\
& End Consumer & - & - & - \\
\hline Total & & - & - & - \\
\hline \multirow{2}{*}{ II } & Breeder & - & - & - \\
& Collecting Merchants & 765.556 & 190.000 & 575.556 \\
& & &
\end{tabular}


International Journal Of Science, Technology \& Management

End Consumer

\begin{tabular}{clccc}
\hline Total & & $\mathbf{7 6 5 . 5 5 6}$ & $\mathbf{1 9 0 . 0 0 0}$ & $\mathbf{5 7 5 . 5 5 6}$ \\
\hline \multirow{3}{*}{ III } & Breeder & - & - & - \\
& Great Traders & 1.088 .571 & 90.000 & 998.571 \\
& End Consumer & - & - & - \\
\hline Total & & $\mathbf{1 . 0 8 8 . 5 7 1}$ & $\mathbf{9 0 . 0 0 0}$ & $\mathbf{9 9 8 . 5 7 1}$ \\
\hline \multirow{4}{*}{ IV } & Breeder & - & - & - \\
& Collecting Merchants & 765.556 & 190.000 & 575.556 \\
& Great Traders & 323.016 & 90.000 & 233.016 \\
& End Consumer & - & - & - \\
\hline Total & & $\mathbf{1 . 0 8 8 . 5 7 1}$ & $\mathbf{2 8 0 . 0 0 0}$ & $\mathbf{8 0 8 . 5 7 1}$ \\
\hline
\end{tabular}

The cost of marketing beef cattle in Landono and Mowila subdistricts of South Konawe Regency on each channel varies, because the institutions involved are different. The costs incurred by the collectors include labor costs (Rp 40.000/tail/person), informants ( Rp 100.000/tail/person) and transportation (Rp $50.000 /$ tail/load), while the costs incurred by large traders include labor costs ( Rp $40.000 /$ tail/person) and transportation (Rp 50.000/tail/person). For channel I, there are no institutions involved so there are no costs incurred, while the cost of marketing beef cattle issued on marketing channel II is Rp 190.000/tail, marketing channel III is Rp 90.000/tail, and marketing channel IV is Rp 280.000/tail. Many of the activities of marketing functions carried out will affect the small amount of marketing costs incurred by marketing actors [22, 23, 24].

\section{CONCLUSION}

Based on the results of the study concluded that:

1. Marketing Line of beef cattle in Landono and Mowila subdistricts, consists of four lines, namely, Farmer $\rightarrow$ The End Consumer (Channel I), Farmer $\rightarrow$ End Consumer $\rightarrow$ Collector Trader (Channel II), Farmer $\rightarrow$ Big Trader $\rightarrow$ End Consumer (Channel III), Farmer $\rightarrow$ Collector Trader $\rightarrow$ Big Trader $\rightarrow$ The End Consumer (Channel IV), while for institutions involved in the marketing process are collectors and large traders.

2. Margin marketing of beef cattle in Landono and Mowila subdistricts, varies. The institutions that have the highest margin are the collecting traders on channel II (Rp 390.476/tail) and the channel that has the highest margin is the marketing channel IV (Rp 686.667/tail).

3. Institutions that have the highest profit on the marketing of beef cattle in Landono and Mowila subdistricts are large traders (Rp 1.088.571/tail) on marketing channels III and the lowest are large traders (Rp 323.016/tail) on marketing channels IV. Meanwhile, the channels that have the highest profit are marketing channels III and IV of Rp 1.088.571/tail, and the lowest is marketing channel II of Rp 765.556/tail. 


\section{ACKNOWLEDGMENTS}

The author thanks the residents of Landono and Mowila subdistricts for their willingness to be respondents in this study, may the good deeds be accepted in the side of Allah SWT.

\section{REFERENCES}

[1] F. Khairad, M. Noer, M. Mahdi, "Economic Growth Analysis of Food Subsector Production Center in West Sumatra Province,” JP2WD, 2, 2018, pp. 171-184.

[2] K. Buditiawan, "Base Sector in Blitar Regency, East Java: PDRB Analysis of Blitar District in 2010-2016," Inovasi, 16, 2019, pp. 85-94.

[3] A. E. Wicaksono, "Base and Non Basis Sector Analysis on Economic Growth in Madiun In 2013-3017," Economicus, 3, 2019, pp. 207-219.

[4] F. Setiawan, "Analysis of Potential Of Base And Non Base Sector of Sabang City in 2013-2019," JAI, 6, 2020, pp. 89-104.

[5] Y. R. Noach, M. F. Lalus, "Analysis of Market Connection Index and Margin Distribution in Beef Cattle Marketing Institutions in Kupang Regency, East Nusa Tenggara, Indonesia," AGRIMOR, 5, 2020, pp. 13-16.

[6] A. H. Abdillah, J. Juraemi, T. P. Daru, "Financial Analysis of Bali Cattle Business (Bos sondaicus) IN P4S Cahaya Purnama Kabupaten Kutai Timur," Ziraa'ah Majalah Ilmiah Pertanian, 44, 2019, pp. 154-162.

[7] N. A. Lasaharu, Y. Boekoesoe, "Beef Cattle Marketing Analysis," Jambura Journal of Animal Science, 2, 2020, 62-75.

[8] U. W. Ningsih, B. Hartono, E. Nugroho, “Analysis of beef cattle marketing through margin analysis, price transmission, marketing structure, marketing behavior and marketing performance," Indonesian Journal of Animal Science, 27, 2017, pp. 1-11.

[9] W. Trizulita, D. P. P. A. Hadiyani, W. E. Susanto, "Marketing analysis of cow's milk in kud karangploso bocek village karangploso district malang district," Jurnal Sains Peternakan, 6, 2018, pp. 1-8.

[10] A. Syahdani, Hasnudi, N. D. Hanafi, "The Income Analysis and Marketing Efficiency of Beef Cattle Business in Langkat District," jpi, 4, 2016, pp. 222-234.

[11] C. D. Nugraha, E. Herwijanti, I. Novianti, A. Furqon, W. Andre, W. Busono, "Analysis of The Relationship of Body Weight to The Production of Fresh Cement Of Bali Cows In The Center for Artificial Insemination- Singosari," Journal of Tropical Animal Production, 20, 2019, pp. 70-75.

[12] T. Afriani, M. P. Agusta, F. Arlina, "Estimated Population Dynamics and Breeding of Beef Cattle in Bayang Subdistrict, South Coastal District," Jurnal Peternakan Indonesia, vol. 21, 2019, pp. 130-142.

[13] N. L. E. Setiasih, I. K. Suatha, P. Suastika, D. N. D. I. Laksmi, "Improving Bali Cattle Productivity Through Health Services In Belok Village Sidan Badung Regency," Buletin Udayana Mengabdi, 18, 2019, pp. 82-88.

[14] B. N. Utomo, "Development of Beef Cattle Based on Palm Oil Plantation Industry," Jurnal Litbang Pertanian, 31, 2012, pp. 153-161. 
[15] S. B. Kusuma, N. Ngadiyono, S. Sumadi, "Estimated Population Dynamics And Appearance of Peranakan Ongole Cattle Reproduction In Kebumen Regency, Central Java Province". Buletin Peternak, 41, 2017, pp. 230-242.

[16] J. Malotes, "Strategy for The Development of Beef Cattle Farming In North Tinangkung District, Banggai Islands Regency ". Jurnal Agroland, 23, 2016, pp. 198-207.

[17] S. N. Karimah, A. Atabany, "Strategy for The Development of Cattle Fattening Bumdes Mekar Pratama Mekarharja Village, Purwaharja District, Banjar City". Jurnal Pusat Inovasi Masyarakat (PIM), 1, 2019, pp. 111-117.

[18] G. Siregar, "Feasibility Analysis And Business Development Strategy of Beef Cattle" Jurnal Agrium, 17, 2012, pp. 192-201.

[19] J. A. Putritamara, N. Febrianto, P. H. Ndaru, "Beef cattle marketing strategy at PT Tunas Jaya Raya Abadi Nganjuk," Indonesian Journal of Animal Science, 28, 2018, pp. 96104.

[20] S. Ayele, "Analysis of Market Structure, Conduct and Performance of Beef Cattle: The Case of Dugda District, East Shoa Zone, Oromia Regional State, Ethiopia,” Journal of Biology, Agriculture and Healthcare, 7, 2017, pp. 5-11.

[21] H. Koesmara, S. Nurtini, I. G. S. Budisatria, "Factors Influencing The Marketing Margin of Beef And Beef In Aceh Besar District," Buletin Peternakan, 39, 2015, 57-63.

[22] H. J. Purba, P. U. Hadi, "Dynamics and Marketing Policy of Beef Cattle Products in Eastern Indonesia,” Analisis Kebijakan Pertanian, 10, 2016, pp. 361-373.

[23] J. Sumantri, T. A. Kusumastuti, R. Widiati, "Beef Cattle Marketing In Ogan Komering Ilir Regency, South Sumatra," Buletin Peternakan, 37, 2013, pp. 49-58.

[24] L. O. A. Sani, L. O. Nafiu, "Marketing Efficiency of Bali Cattle in Kabaena Island Bombana Regency, Buletin Penelitian Sosial Ekonomi Pertanian, 13, 2011, pp. 145149. 